\title{
Obituaries
}

\section{Sir John Vane}

Nobel prize winning pharmacologist who discovered how aspirin works

John Vane's contribution to society was the science underpinning the finding that a daily low dose of aspirin prevents heart attacks and strokes, saving millions of lives each year, and the development of angiotensin converting enzyme (ACE) inhibitors for the treatment of hypertension. He made huge advances to our knowledge of inflammation and in 1982 he won a Nobel prize for medicine or physiology for discovering how aspirin works-sharing it with Sune Bergström and Bengt Samuelsson of Sweden.

He was awarded a Lasker prize (often a precursor to a Nobel) in 1977, which he also shared with Bergström and Samuelsson. In 1984 the British government recognised his outstanding achievements and gave him a knighthood in the New Year honours.

John Vane was born in Tardebigg, Worcestershire. As a boy he blew up the kitchen with a chemistry set, so his father built a shed in the garden in which he could do his experiments. He read chemistry at Birmingham University, graduating at 19 , before taking a degree in pharmacology at Oxford. He graduated in 1949 and went on to a DPhil, spending a year out to lecture in pharmacology at Sheffield University. In 1953 he went to Yale University, Connecticut, for two years, and then returned to England to the Royal College of Surgeons' Institute of Basic Medical Sciences at Lincoln's Inn Fields.

The head of the Institute was Professor William Paton, succeeded by Professor Gustav Born, two of the leading pharmacologists of their day, and they provided a remarkable intellectual environment. John spent 18 years there, ending as professor of experimental pharmacology. This was the most scientifically productive period of his career. Prostaglandins were newly discovered, he had a hunch that aspirin worked by inhibiting their formation, and he showed that aspirin and indomethacin inhibited prostaglandin synthetase. This work also helped trigger the development of the anti-inflammatory drugs the cyclooxygenase-2 (COX 2) inhibitors.

During this time he was a consultant to Squibb, where he backed an idea by a former colleague from Yale that led to

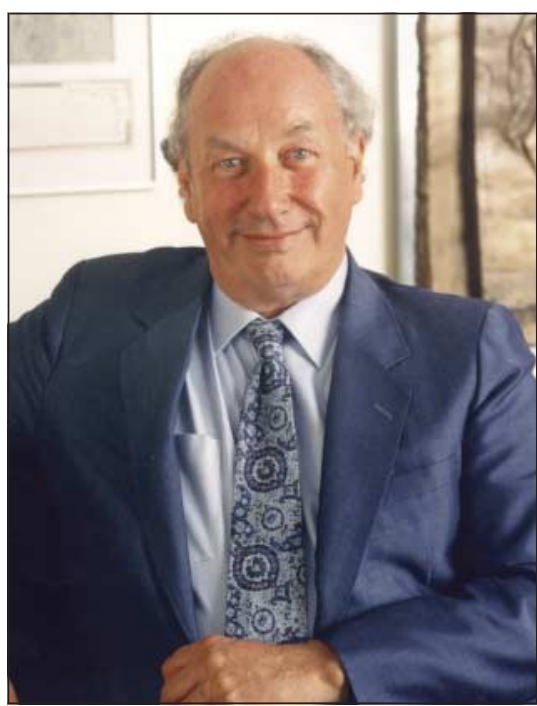

captopril, the first of the ACE inhibitors. Other innovative drugs whose development he oversaw included atracurium, a muscle relaxant, and lamotrigine, an epilepsy drug.

In 1973 he moved to the Wellcome Foundation, attracted at least in part by the idea that the company's profits were gifted to the charitable Wellcome Trust, and because one of his intellectual heroes, the physiologist and Nobel prize winner Sir Henry Dale, had been one of the company's founding fathers. Here he was director of research and development but found little time to do hands-on research. His Wellcome group, along with Richard Gryglewski in Poland, discovered prostacyclin, a shortlived hormone that dilates blood vessels and prevents platelet agglutination.

He was a man with an insatiable curiosity, a good nose for a sound idea, and a nonsense-detector. Colleagues described his leadership as inspirational: one of them, Joe Collier, now professor of medicines policy at St George's Hospital Medical School, London, said, "He taught us how to work, teach, learn, and even how to conduct ourselves as scientists."

At 59, with a Nobel Prize tucked under his belt, he retired from Wellcome but not from work: St Bartholomew's Hospital Medical School invited him to be the nucleus of a new research establishment, the William Harvey Research Institute. It is now one of the top 20 UK research establishments, with 130 scientists.

He retired as a full time director in 1995, when he was 68 , but became director of the charitable William Harvey Research Foundation. In 1991, aged 64, he and a colleague set up a new pharmaceutical company, Vanguard, to develop compounds that the pharmaceutical industry had put to one side for reasons other than toxicity.

He made regular trips to Poland from 1962, often taking chemicals and equipment, and did much to prevent that country's intellectual isolation. In 2003 he was awarded the Polish Order of Merit.

He published over 900 scientific papers, was joint editor of 20 books, collected over 50 awards and medals including honorary fellowship of the Royal College of Physicians, and did much charitable work.

Though basically shy, he was also sociable, generous, and hospitable. From 1973 onwards he made regular winter visits to the Caribbean island of Virgin Gorda, where he and his wife, Daphne, built a house and made a garden, and where they invited friends from around the world.

$\mathrm{He}$ was the target of animal rights extremists, who pursued a campaign against him that was vindictive even by their own standards-his house was firebombed and daubed with graffiti. He responded with characteristic courage, defending the moral use of animals in scientific research, and offering moral support to others who were targeted in a similar way.

He leaves Daphne and two daughters. [CAROLINE Richmond]

John Robert Vane, professor of experimental pharmacology Royal College of Surgeons 1966-73; director of research Wellcome Foundation 1973-85; director, then director-general, William Harvey Research Institute, St Bartholomew's Hospital Medical School, 1986-97; professor of pharmacology and medicine New York Medical College since 1986 (b 1927; DPhil), died from pneumonia on 19 November 2004.

See Reviews $p 1408$ 


\section{Usama Abdulla}

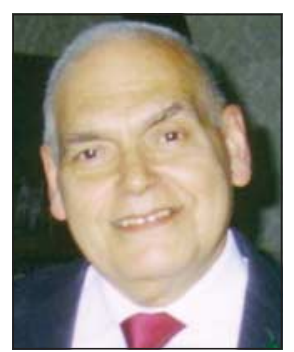

Former consultant obstetrician and gynaecologist Aintree University Hospital, Liverpool (b Baghdad 1937; q Baghdad 1961; FRCOG), died from metastatic cholangiocarcinoma on 3 October 2004.

After national service, in which he saw active service in northern Iraq, Sam Abdulla worked in Baghdad, where he met and befriended the ultrasound pioneer Ian Donald, who had been taken ill on a visit there. He invited Sam to join his unit in Glasgow. That was the beginning of a lifetime passion for ultrasound. He was one of the first to publish on ultrasound placentography and he did important work on the safety of diagnostic obstetric ultrasound at a time when there was concern about chromosomal breakage from this investigation. He introduced obstetric ultrasound to Liverpool, where he delivered the Walton sextuplets in 1983. He leaves a wife, Linda; four children; and a granddaughter. [JoHN SuTHERST]

\section{Matthew Crawford Dickson}

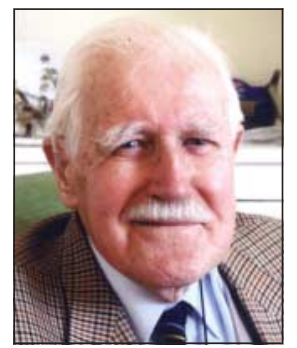

Former general practitioner Glasgow (b Dennistoun 1906; q Glasgow 1932), d 12 October 2004.

Lieutenant "Doc" Dickson is how Matthew is described in a second world war history of his regiment. He survived the rigours of the France/Belgium campaign and the evacuation at Dunkirk, to be sent to the Far East. Captured in Singapore, he was interned in 1942 in Changi Jail and subsequently sent to the Siam-Burma railway. Patients still talk of the emaciated Dr Dickson who returned to work in Glasgow. Matthew worked in his practice for over 40 years, retiring at the age of 70 . He was medical adviser to numerous industrial and commercial companies, including the Glasgow shipyards. Predeceased by his wife, Marion, he leaves a daughter. [GORDON A CLARK, BRYAN L WhITTY]
Samuel Rutherford Fee

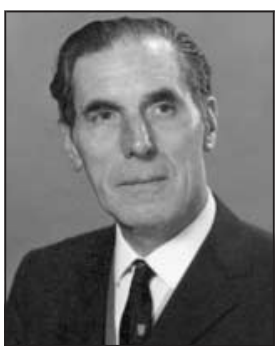

Former general practitioner Tunstall, Stoke-on-Trent (b 1908; q Glasgow 1932; OBE, FRCGP), d 24 July 2004

Samuel Rutherford Fee became an assistant at a practice in Basford, Stoke-on-Trent, in 1936, subsequently becoming a partner in Tunstall. With this came the post of medical officer of Westcliffe Hospital. He also became clinical assistant in medicine at the Haywood Hospital, Burslem. He supported the building of the North Staffordshire Medical Institute in 1963, becoming its first GP chairman in 1972. He was elected a fellow of the BMA in 1968. Failing sight made him retire at 80 . Predeceased by his wife, he leaves three children and seven grandchildren. [JENNIFER WiLton, Alastair Fee, Calum Fee]

\section{Colin Gagen Ford}

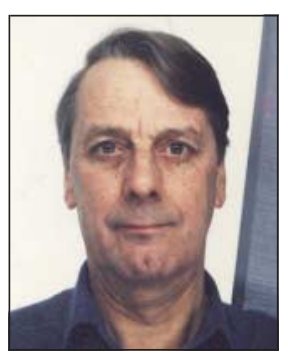

Former general practitioner Chislehurst, Kent (b 1934; q St Mary's Hospital, London, 1962; FRCS), died from pancreatitis as a result of alcoholic liver disease on 29 March 2004. Leaving school at 16 after $O$ levels, he joined Cable \& Wireless and attended evening classes to gain science A levels. After national service with the Royal Marines he returned to complete A levels for medical school entry. He went into general practice, but returned to hospital medicine and an interest in orthopaedics. Considered "too old and too well qualified," he did not succeed in obtaining a place on a training programme, and after several locums returned to general practice. He had a long battle with alcohol and retired on medical grounds. He leaves a wife and four children. [AnN MCARA]

\section{Brian Hayes}

Former consultant general surgeon East Glamorgan Hospital, South Wales (b Tibshelf, Derbyshire, 1929; q Newcastle 1955; FRCS), died from a heart attack and renal failure on 1 September 2004.

Brian held junior surgical jobs in general surgery, urology, and neurology in Newcastle and Bristol. He gained his consultant post as a general surgeon with a specialist interest in urology in 1971 at East Glamorgan General Hospital, Pontypridd. Brian's interests in the outdoors and in Scotland were paramount. He was a keen skier and hill walker, and maintained these hobbies during his retirement, despite illness. He leaves a wife, Edna, and two sons. [Mike Foster]

\section{Richard Lestrem Rees}

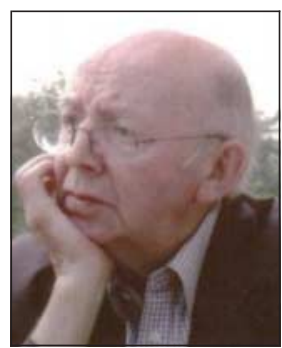

Former consultant orthopaedic surgeon West Wales District General Hospital, Carmarthen (b 1916; q Middlesex Hospital, London, 1939; FRCS), d 12 October 2004.

After graduation and training Dick joined the Royal Army Medical Corps and saw active service on D Day and during the Rhine crossing campaign. He was awarded the Croix de Guerre and mentioned in dispatches. In 1955 he was appointed as the first dedicated orthopaedic surgeon to the South West Wales Hospital Management Committee, serving an area comprising a third of Wales. Following retirement he worked as a visiting professor in Riyadh, Saudi Arabia, and as consultant and adviser in Dacca, Bangladesh, and in Kano, Nigeria. He leaves a wife, Mair; and five children. [DEwI OWEN]

\section{Roger Doidge Willcock}

Former general practitioner Telford (b 1923; $q$ Guy's Hospital, London, 1947), died from ischaemic heart disease and diabetes on 26 March 2004.

After house officer posts he did 18 months' national service in the Royal Navy at Portsmouth and Londonderry. From 1950 he spent the rest of his professional life in general practice, first in Stoke-on-Trent, then Shrewsbury, and finally in Telford. He retired in 1986 and enjoyed nearly 18 years of retirement. He leaves a wife, Jennifer; three sons; and six grandsons. [JENNIFER WillCOCK]

Longer versions of these obituaries are available on bmj.com 